Volume 6

Number 2 Unsolicited Issue

Article 2

$5-1-2020$

\title{
Calibrating Intellectual Property and Innovation in NewSpace
}

Jesse L. Silvernail

JLeeSilvernail@gmail.com

Follow this and additional works at: https://scholarship.law.tamu.edu/journal-of-property-law

Part of the Intellectual Property Law Commons, and the Property Law and Real Estate Commons

\section{Recommended Citation}

Jesse Lee Silvernail, Calibrating Intellectual Property and Innovation in NewSpace, 6 Tex. A\&M J. Prop. L. $113(2020)$.

This Student Article is brought to you for free and open access by Texas A\&M Law Scholarship. It has been accepted for inclusion in Texas A\&M Journal of Property Law by an authorized editor of Texas A\&M Law Scholarship. For more information, please contact aretteen@law.tamu.edu. 


\title{
Calibrating Intellectual Property and INNOVATION IN NEWSPACE
}

\author{
By: Jesse Lee Silvernail
}

\begin{abstract}
The commercial space industry is soon expected to explode into a trilliondollar industry, but patent protection in NewSpace has been largely ignored by an industry that is driven by technological innovation and rapid development. There has been little disclosure of inventions as large commercial space companies rely on trade secrets that are almost impossible to independently invent or reverse engineer. The benefits of both invention disclosure and secrecy are well known, but there has not been analysis on inventions in the space industry. This paper fills the gap in the literature by analyzing common intellectual property practices in the aerospace industry and applying intellectual property theory. I also review past government actions on intellectual property in the aerospace industry. I find that actors in the commercial space industry have little incentive to disclose their inventions. This lack of incentive may harm or slow the expansion of the commercial space industry. This Article may be useful to policymakers who wish to continue the expansion and innovation of the commercial space industry through intellectual property policy.
\end{abstract}

I. Introduction................................ 113

II. Intellectual Property and Innovation Policy ... 115

A. Patent Law and Its Effect on Innovation .......... 116

1. Patent Law Basics ....................... 116

2. Patents and Innovation ................. 117

B. Trade Secret Law and Its Effect on Innovation ..... 121

1. Trade Secret Law Basics ................... 121

2. Trade Secrets and Innovation ............... 122

III. InNovation in the Space Industry ............... 124

A. Historical Aerospace Innovation and Intellectual Property ................................. 125

1. The Wright Brothers' Patent War............ 125

2. United States Ownership of Space Related Inventions ................................ 127

B. Innovation in NewSpace .................... 128

IV. Balancing Secrecy and Disclosure in NewSpace. 131

A. The Free-Market Approach ................... 132

B. The Active Government Approach .............. 133

V. Conclusion .................................... 136

\section{INTRODUCTION}

A new era of commercial launch and satellite companies have entered the aerospace industry, driving a space renaissance that has been predicted to grow into a multi-trillion-dollar sector in the next thirty 
years. ${ }^{1}$ While space exploration has traditionally been under the government's purview, economic incentives are driving these private actors, referred to collectively as "NewSpace," into the as-of-yet untapped final frontier of outer space to take advantage of the unique opportunities and vast resources it holds.

Since the writing of the United States Constitution, the government has always had a hand in incentivizing innovation through legislation. The primary policy tool for general technological innovation has long been patent law. Trade secret law also plays an important part in innovation policy with some scholars supporting secrecy's place in technological innovation use while others condemn it.

The government has traditionally tightly controlled innovation in the space industry, but there has been a shift away from governmentbacked-development to the private-investor-backed-development of NewSpace companies. The government has shown they are willing to directly control space related innovation in the past through legislation and agency action. As NewSpace actors grow and innovation in the space industry shifts away from NASA, the current legislation ensuring public benefit of space related technologies, which rely on government development of space technologies, loses relevance.

A possible monopoly formation in the space launch sector has occurred as SpaceX has increased their market share. Lower prices drive this monopoly because of new technologies with details that are kept secret. The lack of competition could potentially harm innovation in the industry long term, and this would be bad for the NewSpace industry and the public because NewSpace technologies rely on launch companies to get to space.

In this Article, I will examine the advent of NewSpace in the light of intellectual property and innovation policy. In Section I, I examine the basics of intellectual property and innovation policy. In Section II, I will look at the history of legislation around intellectual property in the aerospace industry and current actions of NewSpace companies. In Section III, I will discuss if legislative action should be taken in order to promote innovation in the emerging NewSpace environment or ensure NewSpace benefits the public.

I conclude that the best way to ensure continued innovation in the industry is to promote the patenting of space related technologies by using government contracts. Once these technologies begin to be patented, a patent pool could be created to break a monopoly on the launch industry if it is still a problem. Keeping NewSpace innovation in the United States is critical because of the vast economic potential and national security.

DOI: https://doi.org/10.37419/JPL.V6.I2.2

1. See Michael Sheetz, The space industry will be worth nearly $\$ 3$ trillion in 30 years, Bank of America predicts, CNBC (Oct. 31, 2017, 2:08 PM), https:// www.cnbc.com/2017/10/31/the-space-industry-will-be-worth-nearly-3-trillion-in-30years-bank-of-america-predicts.html [https://perma.cc/W88J-UHAX]. 


\section{Intellectual Property and Innovation Policy}

Inventors must carefully consider their intended use of the invention before they make the choice of how to protect it. The choice to patent an invention or keep it a trade secret is unique in intellectual property law in that choosing one prevents the other. ${ }^{2}$ Patenting an invention or discovery requires disclosure of the invention or discovery. ${ }^{3}$ Trade secrecy requires secrecy by nature, so disclosure of an invention prohibits its use. ${ }^{4}$ Alternatively, inventors can disclose their inventions and choose not to protect them, but that choice and its benefits are outside the scope of this Article.

Thus, patents and trade secrets offer vastly different benefits, and in choosing a form of protection inventors must consider their own situation and weigh the benefits of using patent, trade secret, or a combination of the two to protect their intellectual property. Actors within the same industry tend to pick the same methods of protection, as the benefits and disadvantages of their choice of protection are generally the same. The methods an industry uses to invent and profit off those inventions are considerations companies must use to determine the intellectual property strategy with the greatest benefit for them. Additionally, policy makers must consider these methods to determine the intellectual property policy that will lead to innovation and societal benefit.

There is a longstanding debate about the merits of both patents and trade secrecy as means of protecting inventions and encouraging innovation. ${ }^{5}$ Patents are generally accepted on utilitarian grounds because the grant of a monopoly, as well as the returns that come with a noncompetitive market, encourages development of new and valuable information. ${ }^{6}$ On the other hand, trade secrets are traditionally thought

2. See generally Trade Secret Policy, U.S. Pat. \& Trademark Off., https:// www.uspto.gov/patents-getting-started/international-protection/trade-secrets-policy [https://perma.cc/6MAH-7R4E] (last visited Sept. 6, 2019). Patenting an invention requires disclosure, and trade secret law inherently requires its subject to be a secret. Therefore, patenting an invention precludes it from being a trade secret after the patent application is published.

3. See 3 Donald S. Chisum, Chisum on Patents $§ 7.01$ (2019) ("To obtain a valid patent claiming a new, useful, and nonobvious product or process, the inventor must file with his or her application a specification fully disclosing the invention and how to make and use it."). 1985).

4. See Uniform Trade Secrets Act § 1(4)(ii) (Unif. Law Comm'n amended

5. See Mark A. Lemley, The Surprising Virtues of Treating Trade Secrets as IP Rights, 61 StAn. L. Rev. 311, 313 (2008) ("[T]rade secret law actually encourages disclosure, not secrecy."); see also J. Jonas Anderson, Secret Inventions, 26 BERKELEY TECH. L.J. 917, 921 (2011) ("[T]rade secrets and patents should be viewed not as opposing systems of invention protection, but rather as complementary tools for policy makers."); Michael Risch, Why Do We Have Trade Secrets, 11 Maro. InTELl. Prop. L. Rev. 1 (2007) ("[C]reating incentives to innovate is a very minor justification of trade secret law.").

6. Lemley, supra note 5, at 329. 
to be antithetical to patent law as they conceal valuable information from the public. ${ }^{7}$ However, modern scholars are starting to view trade secrets as another method of encouraging innovation. ${ }^{8}$ Despite this new view of secrecy, the commercial space industry's reliance on secrecy to protect their inventions may be contrary to the public good. ${ }^{9}$

The inherent lack of both competing companies and the public's direct access to technology in the space industry prevents the below discussed drawbacks to trade secrecy that normally balance its benefits. In this Section, I will discuss the basics of patent law and trade secret law and their relationship with influencing innovation.

\section{A. Patent Law and its Effect on Innovation}

\section{Patent Law Basics}

The patent system represents a bargain between inventors and the public in that it rewards those who disclose their inventions with a time-limited monopoly. ${ }^{10}$ Granting patents has rewarded innovation in the United States since its founding, as evidenced by the United States Constitution granting Congress the power to "promote the progress of science and useful arts, by securing for limited times to authors and inventors the exclusive right to their respective writings and discoveries." so that innovations will be disclosed, as opposed to being kept secret. However, patent protection has significant limitations that may discourage it from being used in certain situations.

Patent law offers protection for a wide but still limited scope of discoveries. According to Section 101 of the Patent Act, patentable subject matter is "any new and useful process, machine, manufacture, or composition of matter, or any new and useful improvement thereof." ${ }^{2}$ Courts have further clarified this definition of patent eligible subject matter to exclude anything naturally occurring, including abstract ideas, physical phenomenon, and laws of nature. ${ }^{13}$ While the limited scope of patentable subject matter can restrict the usefulness of patents in certain situations or industries, generally innovators use patents widely and effectively to secure the rights to their inventions.

7. See Anderson, supra note 5, at 919 ("Patents are often conceptualized as a means of luring secret inventions out of the dark, shadowy cave of trade secrecy, and into the bright, public sunlight of the patent system.").

8. $C f$., Lemley, supra note 5, at 313 ("[T] rade secret law actually encourages disclosure, not secrecy.").

9. See infra Section II.B.

10. Pfaff v. Wells Elecs., Inc., 525 U.S. 55, 63 (1998) ("[T]he patent system represents a carefully crafted bargain that encourages both the creation and the public disclosure of new and useful advances in technology, in return for an exclusive monopoly for a limited period of time.").

11. U.S. Const., art. I, \& 8, cl. 8.

12. 35 U.S.C. $\S 101$ (2012).

13. Mayo Collaborative Servs. v. Prometheus Labs., Inc., 566 U.S. 66, 70 (2012). 
Patent protection is also limited in duration. The United States Constitution requires that patent rights last for a limited amount of time. ${ }^{14}$ For a patent application currently filed within the United States, patent protection generally lasts twenty years from the date on which the application for the patent was filed. ${ }^{15}$ Limitations on the duration of patent protection must be weighed alongside commercial lifespan of a product in deciding whether to seek a patent to protect an invention.

Patents are also difficult to obtain and maintain. Obtaining a patent is often a lengthy process that requires a significant monetary and time investment. In 2001, it was estimated that the patent prosecution process alone costs $\$ 10,000-\$ 30,000 .^{16}$ The cost has most likely increased since then. On average, a patent takes five years to issue from the filing date. ${ }^{17}$

\section{Patents and Innovation}

Patents are largely considered to be a centerpiece for encouraging innovation. Patents encourage innovation because granting a monopoly on an invention allows inventors to make a profit in a market with no competitors. ${ }^{18}$ Patents reward innovation and the disclosure of new information with a time-limited monopoly. These time-limited monopolies represent a balance between rewarding innovation and the dangers of granting an exclusive monopoly. ${ }^{19}$ However, despite this balance some scholars believe that patents hinder innovation. ${ }^{20}$

Patents encourage innovation by giving innovators a chance to profit off their work. Invention has an implicit economic risk because it requires the use of resources, such as time and money, without a guarantee of profiting or even recouping the spent resources. ${ }^{21}$ Inventors are less likely to take a risk investing in an invention when others

14. See U.S. Const., art. I, $\S 8$, cl. 8 .

15. 35 U.S.C. $\$ 154(\mathrm{a})(2)$ (2012).

16. Mark A. Lemley, Rational Ignorance at the Patent Office, 95 Nw. U.L. REv. 1495, 1498 (2001).

17. See Anderson, supra note 7 at 957.

18. See Mark A. Lemley, Property, Intellectual Property, and Free Riding, 83 TEx. L. REV. 1031, 1054 (2005) ("In a private market economy, individuals will not generally invest in invention or creation unless the expected return from doing so exceeds the cost of doing so - that is, unless they can reasonably expect to make a profit from the endeavor.").

19. See Bonito Boats v. Thunder Craft Boats, 489 U.S. 141, 146 (1989) ("The Patent Clause itself reflects a balance between the need to encourage innovation and the avoidance of monopolies which stifle competition without any concomitant advance in the 'Progress of Science and useful Arts.'").

20. E.g., Michele Boldrin \& David K. Levine, Against Intellectual MoNOPOLY (2008).

21. See Lemley, supra note 18, at 1053 ("[T]he basic economic justification for intellectual property law comes from what was only an occasional problem with tangible property-the risk that creators will not make enough money in a market economy to cover their costs."). 
can also take advantage of said invention. ${ }^{22} \mathrm{~A}$ patent grants a monopoly on an invention for a period of time because it allows the owner to exclude others from that invention. This monopoly allows the invention to exist in a market free of competitors, increasing the chance that an invention will be profitable. Inventors are more likely to innovate and take that economic risk when they have a monopoly over their invention and a greater chance to profit.

The patent system also encourages innovation by promoting the disclosure of new information to the public. ${ }^{23}$ Patent owners are granted a monopoly as quid pro quo for the disclosure of their invention. ${ }^{24}$ The disclosure requirement of the patent system benefits innovation in several ways.

Disclosure of an invention ensures that society can freely use or create the invention after a patent's term expires, and the inventor no longer has a monopoly over their invention. ${ }^{25}$ Even though a monopoly on an invention seems antithetical to a free market, if the invention was never disclosed, it is possible no one but the inventor would ever benefit off of the invention. Additionally, disclosure also encourages competition after a patent's term expires, and many believe competition leads to further innovation.

Disclosure can also benefit innovation during the term of the patent because disclosure can cause others to design around the patented invention or to create new inventions. ${ }^{26}$ Inventors can see a disclosed invention from a patent and improve upon the invention; design around the invention to solve the same problem in a different way; or be inspired by the invention in some other way. ${ }^{27}$

There are scholars who believe that the patent system harms innovation. The right to buy and sell copies of an idea is generally accepted as good policy because it allows inventors to profit off of their ideas. ${ }^{28}$ However, the right of inventors to control how purchasers of an idea make use of the idea is controversial because it creates an "intellectual monopoly."29 Monopolies are widely accepted to create social costs and are only worth these social costs if the monopoly creates benefits

22. See Bilski v. Kappos, 561 U.S. 593, 650 (2010) (Stevens, J., concurring) ("[S]cholars generally agree that when innovation is expensive, risky, and easily copied, inventors are less likely to undertake the guaranteed costs of innovation in order to obtain the mere possibility of an invention that others can copy.").

23. See Jeanne C. Fromer, Patent Disclosure, 94 Iowa L. Rev. 539, 548 (2009) ("The theory is that [innovation] occurs by rewarding inventors for taking two steps they likely would not otherwise take: to invent in the first instance and to reveal information to the public about these inventions.").

24. Pfaff v. Wells Elecs., Inc., 525 U.S. 55, 63 (1998).

25. See Fromer, supra note 23, at 548.

26. Id. at 548-549 (2009).

27. $I d$.

28. BoldRIN \& LeVINe, supra note 20 , at $8-9$.

29. Id. 
that outweigh its costs. ${ }^{30}$ Innovation has been shown to be possible and profitable without the use of intellectual monopolies. ${ }^{31}$ In fact, there seems to be a pattern that industries follow: a pioneering stage, in which intellectual property plays no role, where new inventions and better goods emerge; followed by a stage where innovation slows and intellectual property becomes widely used and enforced. ${ }^{32}$ If the NewSpace industry follows this pattern, we are currently in the pioneering stage of innovation and have yet to see the effects of increased intellectual monopoly enforcement and slowing innovation.

Economists generally consider monopolies to have a negative economic and societal impact. Monopolies are traditionally thought to be inefficient because they create artificial scarcity to secure more profit, but more modern economists believe that monopolies are generally inefficient and use unreasonably costly production methods. ${ }^{33}$ More relevant to innovation, monopolies stifle innovation because they prevent others from entering into a market with the goal of generating more wealth for themselves. ${ }^{34}$ Monopoly's cost on innovation is difficult to quantify, ${ }^{35}$ but monopolies should be assumed problematic and viewed skeptically unless a significant social benefit can be obtained from their use.

Assuming monopolies are generally considered disadvantageous for society, the question of whether intellectual monopolies encourage innovation comes down to if the increase in profit in a monopoly system over a competition-based system encourages innovation enough to overcome the costs of monopoly. Economists have shown that there is no empirical evidence linking patents to innovation or productivity. ${ }^{36}$ However, "the empirical evidence is consistent with the proposition that greater competition, not patents, is the main factor leading to innovation and greater productivity." ${ }^{37}$ The issue of monopolies granted over intellectual property remains contentious, but it must be considered when looking at intellectual property's effect in an industry.

The quality of issued patents is another issue that affects innovation. Many critics argue that the United States Patent and Trademark

30. Id ; but see Joseph Alois Schumpeter, Capitalism, Socialism and DeMOCRACY (1942) (arguing that some degree of monopoly is preferable to perfect competition).

31. BOLDRIN \& LeVINE, supra note 28, at 17-74 (stating that innovations in the computer, software, and other industries were largely made without intellectual monopoly).

32. Id.

33. Id. at $75-108$.

34. $I d$.

35. Id.

36. Michele Boldrin \& David K. Levine, The Case against Patents 27, J. OF Econ. PERSP. 3, 7 (2013) ("[I]t is fair to say that the sector-level, national, and cross-national evidence fail to provide any clear empirical link from patents to innovation or to productivity.")

37. Id. at 7 
Office is issuing patents of questionable quality. ${ }^{38}$ These "questionable patents" are often patents that can be found invalid if challenged. ${ }^{39}$ As one scholar describes, "[q]uestionable patents can harm competition and hinder innovation by forcing market participants to pay licensing royalties, incur substantial legal expense to defend against infringement claims, engage in design around efforts that raise costs and/or hinder product performance." 40 While new methods of patent quality control, such as Inter Partes Review, have emerged, critics of the patent system continue to claim that questionable patent quality is harming innovation. ${ }^{41}$

One example of the negative effects of lower quality patents and monopoly on innovation is the patent thicket. "Patent thickets" have been described as "a dense web of overlapping intellectual property rights that a company must hack its way through in order to actually commercialize new technology." ${ }^{42}$ This means that multiple patents held by different entities are required to complete an invention. ${ }^{43}$ Effectively, this results in a "tragedy of the anticommons" where multiple rights holders have the right to exclude each other from resources, causing no one to be able to effectively use the resources. ${ }^{44}$ The potential for these compounding effects can be seen in a variety of industries, including biomedical and telecommunications. ${ }^{45}$ One especially worrying case of patent thicket in effect is the pharmaceutical industry, where the use of many patents may prevent the development of a lifesaving drug. ${ }^{46}$

38. Lemley, supra note 16, at 1495 ("The PTO has come under attack of late for failing to do a serious job of examining patents, thus allowing bad patents to slip through the system.").

39. See Carl Shapiro, Patent System Reform: Economic Analysis and Critique, 19 Berkeley TeCh. L.J. 1017, 1018 (Summer 2004) ("Complaints regarding the patent system typically allege that the U.S. Patent and Trademark Office (USPTO) issues many questionable patents, for example, patents that are likely to be invalid or contain overly broad claims.").

40. Id. at 1019.

41. Neal Solomon, The Myth of Patent Quality, IP Watchdog (July 25, 2017), http://www.ipwatchdog.com/2017/07/25/myth-patent-quality/id=86021/ ("The solution to these perceived problems was creation of a second window of patent examination in the Patent Office in the form of post-grant reviews, including Inter-Partes Review (IPR), Post-Grant Review (PGR) and Covered Business Method (CBM).").

42. Carl Shapiro, Navigating the Patent Thicket: Cross Licenses, Patent Pools, and Standard Setting, in 1 Innovation Pol'y \& ECON. 119, 120 (2000).

43. Id.; see also David J. Teece, The "Tragedy of the Anticommons" Fallacy: A Law and Economics Analysis of Patent Thickets and FRAND Licensing, 32 BERKELEY TECH. L.J. 1490, 1492 (2017).

44. See Michael A. Heller \& Rebecca S. Eisenberg, Can Patents Deter Innovation? The Anticommons in Biomedical Research, 280 SCIENCE 698 (May 1, 1998).

45. Michael A. Heller, The Tragedy of the Anticommons: A Concise Introduction and Lexicon, 76 Mod. L. Rev. 6, 6-7 (Jan. 2013).

46. See id. at 6. See generally Heller \& Eisenberg, supra note 44. But see Teece, supra note 43, at 1492 ("The existence of products that require licenses from multiple patent owners supposedly leading to what Heller and Eisenberg characterize as a 
Patents undoubtedly have a significant impact on innovation. However, patents are barely used in NewSpace, especially for launch-related-technologies. Trade secret protection seems to be the dominant form of invention protection. Trade secrets are the opposite of patents in many ways, but they are as important a consideration as patents when considering innovation policy and its effect within the space industry.

\section{B. Trade Secret Law and its Effect on Innovation}

\section{Trade Secret Law Basics}

While the patent system rewards disclosure, trade secret protection depends on, as the name implies, keeping an idea secret. Federal law has traditionally favored patent protection as a means of encouraging disclosure of inventions and subsequently innovation. ${ }^{47}$ However, trade secret law does not abide by the limitations of patent law, and there are many situations when trade secret protection is a more favorable choice for inventors. There is a current debate in the trade secret literature whether trade secret protection encourages innovation or if it is antithetical to the policy goals backing patent law. ${ }^{48}$ This section will explore the required trade secret protection elements and how these elements affect views on innovation policy.

Trade secrecy offers protection for a wider scope of information than patent law. Generally, any information that has independent economic value and has been the subject of reasonable protections to maintain secrecy is eligible for trade secret protection. ${ }^{49}$ Information with independent economic value is generally any information that gives any competitive advantage. ${ }^{50}$ Whether reasonable protections to maintain secrecy were employed is more difficult to define because it is highly fact specific and jurisdiction dependent. ${ }^{51}$ Generally, when looking at whether an enterprise uses reasonable protections to maintain secrecy, courts consider the size and sophistication of an enterprise, its location and scope of business, and the nature of its employees. ${ }^{52}$ For example, a large computer technology company in Silicon Valley would be required to have greater protections on se-

"tragedy of the anticommons" does not, in practice, seem to lead to serious problems.").

47. Jason Mazzone \& Matthew Moore, The Secret Life of Patents, 48 WASHBurn L.J. 33, 35 (Fall 2008) ("Federal law . . expresses a clear preference for the inventor who discloses an invention to the public and obtains a patent over the inventor who keeps the invention a secret.").

48. See Lemley supra note 5; Anderson supra note 5; Risch supra note 5.

49. See Uniform Trade Secrets Act § 1(4) (Unif. Law Comm'n amended 1985).

50. See 1 Roger M. Milgrim, Milgrim on Trade Secrets, § 1.07A (2019).

51. Id., at $\S 1.04$.

52. Id. 
crecy of its information than a single rural carpenter because it is larger; is a more sophisticated business technologically; has more valuable information; and its employees often move between different companies.

Trade secrecy has a few other advantages over patent law. Unlike a patent, the duration of a trade secret is potentially limitless. ${ }^{53}$ Trade secret protection lasts until the information under protection no longer falls under the trade secret eligible subject matter discussed above. There is also no administrative regime for trade secrets, meaning there are no costly applications that take a long time to process. ${ }^{54}$

\section{Trade Secrets and Innovation}

Trade secrets are highly involved in the commercialization of inventions, so it is safe to assume their use influences technological innovation. The magnitude of trade secret law's effect on incentivizing innovation is contentious. ${ }^{55}$ Like patents, trade secrets give a financial advantage to inventors. However, unlike patents, trade secret law promotes keeping new information secret because of its requirement for secrecy. Trade secrecy protects some new information that would never have been patentable, ${ }^{56}$ but there is often overlap in protectable subject matter.

Unlike patents, which incentivize innovation by granting a monopoly for innovators to profit, trade secrets promote innovation through competition over innovative ideas. ${ }^{57}$ Trade secret holders cannot exclude others from using their innovations like patent holders unless their trade secrets are misappropriated. This leaves room for competitors to invest in the same or similar information and compete in the same market. For example, the monopoly granted by a patent can reduce the incentive to improve upon a technology and commercialize it. ${ }^{58}$ On the other hand, the possibility of trade secret holders' competitors independently inventing or reverse engineering to obtain a similar product motivate trade secret holders to improve and commercialize their inventions. ${ }^{59}$ Trade secret holders must innovate and commercialize their innovations over competitors to make a

53. See Anderson, supra note 5, at 924 ("[A] trade secret has a potentially limitless lifespan, while a patent is constitutionally time-limited.").

54. Id. at 952.

55. Compare Risch, supra note 5, at 26-27 ("[C]reating incentives to innovate is a very minor justification of trade secret law.") with Anderson, supra note 5, at 949 ("The innovative benefits of trade secrecy have often been overlooked by courts and commentators.").

56. Milgrim, supra note 50.

57. See Anderson, supra note 5, at 949.

58. Id. at 950 ("The monopoly control of a patent may reduce the incentive to improve upon the patented technology.").

59. Id. 
profit. This competition puts firms in a constant struggle to "one-up" each other, creating a series of innovations for the public benefit.

Trade secret law also gives an incentive to invent because, like patent law, it allows developers of new information to get increased returns that would otherwise not be available. ${ }^{60}$ Trade secret law achieves this by giving developers of new information a way to restrict others from its use. ${ }^{61}$ Trade secret law covers broader subject matter than patent law, so it encourages that development of information that would not otherwise be available. As discussed above, trade secret law also has different limitations than patent law, and in some situations, inventors will be able to profit more from keeping their invention secret than patenting it. ${ }^{62}$ If the use of trade secrets creates the potential for a higher return, the corresponding increased incentive for innovation follows.

Strong laws protecting trade secrets also guarantee innovators can spend capital and make decisions efficiently, increasing innovation overall. Trade secret law's legal protection replaces a need for both increased physical security on a premises and impractical levels of caution in business dealings. ${ }^{63}$ Without trade secret protection, resources that could be spent on innovating or commercializing a product may instead be spent on excessive protection of secrets. ${ }^{64}$ Companies in countries without strong trade secret protection sometimes take innovation-inefficient actions, such as not contracting production to third parties, even if it would be more efficient; or building elaborate walls and fences. ${ }^{65}$

Trade secret law inherently lacks one important pro-innovation function of patents-disclosure of inventions. Disclosure is thought to be one of the main drivers of innovation in patent law, while the traditional view of trade secrets is that they are antithetical to dissemination of information. ${ }^{66}$ However, this may not be as big of a drawback

60. Lemley, supra note 5, at 329.

61. Id. at 330.

62. See Anderson, supra note 5, at 954 (" $[\mathrm{T}]$ he private value of a trade secret, S, can be greater than the private value of a patent, $\mathrm{P}$. When $\mathrm{S}>\mathrm{P}$, economic theory predicts that secrecy will provide greater incentives to invent than patenting.").

63. See Lemley, supra note 5, at 333-34 ("[T] he legal protection trade secret law provides serves as a substitute for investments in physical secrecy that companies might otherwise make.").

64. See Risch, supra note 5, at 43 ("[T] he law of trade secrets is necessary to cause less money to be spent on the protection of secrets, and as a result to cause less money to be spent by those trying to appropriate someone else's trade secrets, even if that means misappropriation is successful more often.").

65. Lemley, supra note 5, at 334-35.

66. See Fromer, supra note 23, at 548 ("The theory is that [innovation] occurs by rewarding inventors for taking two steps they likely would not otherwise take: to invent in the first instance and to reveal information to the public about these inventions."); see also Anderson, supra note 7, at 919 ("Reliance upon trade secrecy, it is thought, leaves the know-how surrounding valuable inventions in the hands of a select few."). 
as previously thought. Inventions that are inherently self-disclosing have no use for trade secret law. ${ }^{67}$ However, inventions that are secret or behind-the-scenes by nature are another matter. There can be little benefit to patenting such innovations, if they are even patentable. Some scholars argue that trade secret law encourages disclosure of this typically secret information by offering legal protection if the information is misappropriated. ${ }^{68}$

Trade secrets and patents are both viable methods of intellectual property protection that encourage innovation in their own way. The choice to use a patent or trade secret for protection is up to the inventor if both are available, and they each have their advantages and disadvantages. Policy makers should also consider their effect on innovation in relation to what inventors will tend to choose within an industry. In the emerging commercial space industry, policy makers should consider intellectual property's impact to innovation by analyzing the history of innovation in the aerospace industry and the current NewSpace companies to ensure innovation that can benefit the public continues.

\section{InNOVAtion IN THE Space Industry}

When novel industries, such as the commercial space industry, emerge into the marketplace, there is often no cohesion on forms of intellectual property protection until a dominant method emerges. The benefits and disadvantages of intellectual property protection in emerging technologically driven industries should be weighed preemptively so the public can receive the greatest benefit. The burgeoning private space industry is unique in a variety of ways and requires consideration on how the public can best benefit from it.

The space industry has a history of relying on government contracts for income, but this is changing as more independent investor money is being injected into a variety of space related projects. ${ }^{69}$ Many of these inventions are used in either launch vehicles, such as rockets, and satellites. These vessels for inventions are the subject of many technological developments, but these technological developments are often not disclosed in order to protect a company's competitive advantage as they seek to become the first in the untapped market of the final frontier.

67. See Lemley, supra note 5, at 313.

68. Id. ("[I]f trade secret law prevented the use of ideas whether or not they were secret, the result would be less, not more, diffusion of valuable information."); see also Risch, supra note 5, at 38 ("[T]his particular social cost [of secrecy] is minimal because the information would already be kept secret by the owner in the absence of trade secret law while others would attempt to discover the same information independently.").

69. See Space Investment Quarterly: Q4 2017, Space Angels (Jan. 18, 2018), https:// www.spaceangels.com/post/space-investment-quarterly-q42017. 
There is currently a lack of competition in the space launch industry. The few companies that dominate the industry have financial, personal, and governmental resources that others cannot access. These companies are secure in their own position in the market without real competition. They have little reason to patent and disclose their new technologies when no one else can realistically obtain the resources needed to reverse engineer or develop a similar technology. This section will start by reviewing the past aerospace industry's problems with intellectual property and their solutions to determine if action should be taken to encourage innovation in NewSpace currently. Then, I will analyze the space launch industry, which controls the rest of the space industry's access to space, to determine if its practices will hinder innovation in the industry.

\section{A. Historical Aerospace Innovation and Intellectual Property}

\section{The Wright Brothers' Patent War}

Problems with intellectual property have been seen before in the aerospace industry. In fact, the aerospace industry began with innovation hindered by overzealous patent enforcement. In 1906, Orville and Wilbur Wright received a patent for their infamous "flying machine." ${ }^{70}$ The most important innovative aspect of their patent was their method of controlling flight through adjusting the "lateral margins" of wings-effectively a broad method of changing the lift area on each wing as a method of stabilizing and controlling flight. ${ }^{71}$ The broad language in the patent allowed the Wrights to obtain a monopoly over early flight control. ${ }^{72}$ Despite the Wright brothers' patent, competitors entered into the burgeoning airplane industry with a variety of new and innovative designs. ${ }^{73}$ Instead of continuing their ingenious innovations in flight, the Wright brothers changed their focus to hindering innovation through excessive patent litigation.

Between 1909 and 1917, the Wright brothers filed many patent litigation lawsuits against competitors. ${ }^{74}$ The Wright brothers' lawsuits spanned the globe with cases across European and United States courts. ${ }^{75}$ The Wright brothers' efforts went so far in enforcing their patent rights that they have been referred to as the "pioneers of patent trolling." 76 The Wrights focused so much on litigation that they neglected research and development of their own, and by 1915, when Orville sold their company, the Wright brothers airplanes were obso-

70. U.S. Patent No. 821,393 (filed Mar. 23, 1903).

71. Id.

72. Sean Trainor, The Wright Brothers: Pioneers of Patent Trolling, Time Mag.

(Dec. 17, 2015), http://time.com/4143574/wright-brothers-patent-trolling/.

73. Id.

74. Id.

75. Id.

76. $I d$. 
lete. ${ }^{77}$ The Wright brothers' litigation hindered innovation throughout the United States airplane industry. ${ }^{78}$ The industry fell so far behind that when the United States sought to enter World War I in 1917, "the state of domestic aviation was so dismal that the U.S. government could not find a single American aircraft fit for military service." ${ }^{\prime 79}$

In order to fix this problem, in 1917, Congress passed a naval appropriations bill which "... enable[d] the Secretary of War and the Secretary of the Navy to secure by purchase, condemnation, donation, or otherwise, such basic patent or patents as they may consider necessary to the manufacture and development of aircraft in the United States." 80 The National Advisory Council for Aeronautics ("NACA") utilized this new power with the promise of increased airplane orders from the United States government and the threat of taking away patent rights to encourage the Wright-Martin Corporation (the successor to the Wright brothers and owner of their patents) and other aviation firms to join an agreement. ${ }^{81}$ This agreement effectively created a patent pool, as it required all airplane manufactures to join the Aircraft Manufacturers Association and to cross-license all owned aviation patents to other members of the organization. ${ }^{82}$ Members were then required to pay royalty fees to the Wright-Martin Corporation and other aviation patent holders until their relevant patents expired. ${ }^{83}$ The creation of this patent pool ended the Wright patent's monopolistic control that hindered the United States aviation industry.

This story illustrates the dangers of monopoly if it effectively covers the whole industry. A lack of competition in the industry harmed the American aviation innovation at its beginning. This is applicable to the NewSpace industry because a monopoly over space launches is emerging. It also shows how the aerospace industry is critical to national security in that maintaining innovation in the commercial sector is critical for the United States to maintain security interests in outer space. The United States government should observe the past and act so the entire industry is not stunted once again by a monopoly born of companies overprotecting intellectual property to the extent that it is not available for the public benefit.

77. Id.

78. $I d$.

79. Id.

80. SP-4103 Model Research - Volume 1, NASA https://history.nasa.gov/SP-4103/ ch2.htm (last visited Sept. 14, 2019). See also The Wright-Smithsonian Controversy: The Patent Pool, Wright Bros. Airplane Co., http://www.wright-brothers.org/History_Wing/History_of_the_Airplane/Doers_and_Dreamers/

Wright_Smithsonian_Controversy/08_The_Patent_Pool.htm (last visited Oct. 2, 2019).

81. See SP-4103 Model Research - Volume 1, NASA https://history.nasa.gov/SP4103/ch2.htm (last visited Sept. 14, 2019).

82. Id. at 40 .

83. Id. 


\section{United States Ownership of Space Related Inventions}

History shows that the government has not hesitated to monitor and control intellectual property rights of space related inventions to promote innovation, ensure national security, and guarantee that space exploration can benefit all. The space industry has traditionally been primarily driven by government actors, as opposed to private ones. Since its founding, the National Aeronautics and Space Administration ("NASA") has either directly developed or contracted out the development of most space related technologies in the United States. Congress and NASA have together pushed laws and policies in support of using NASA's role as the primary driving force in the space industry to support innovation and benefit the public.

The United States first established special procedures to determine ownership of space related inventions in the National Aeronautics and Space Act. ${ }^{84}$ In this statute, Congress granted NASA exclusive ownership of any invention if the "invention is made in the performance of any work under any contract of [NASA]." 85 In the past, there has been minimal incentive for an entity to develop space related technologies outside of a NASA or government contract. Combined with the broad language of the statute, this effectively gave NASA ownership of all space related inventions.

While many of NASA's patents come from the aforementioned compulsory licensing, NASA has also developed programs so members of the public can benefit from their patented technologies. Anyone can apply to license a NASA owned patent and commercialize the technology for the public benefit. ${ }^{86}$ There is a program in place to incentivize startups based on commercializing NASA owned technologies ${ }^{87}$ NASA has recently been releasing technologies it owns patents on into the public domain. ${ }^{88}$

The United States has taken an active role in the past in encouraging innovation in the space industry by controlling intellectual property rights in the space industry. As the industry shifts towards commercial actors being the norm, the United States will lose their ownership of a majority of space inventions. This means they will also lose their ability to license out the use of these inventions for the public benefit. NewSpace companies will have the ability to commercialize and monetize space inventions going forward, and the shift may affect innovation in the industry.

84. See 42 U.S.C. $§ 2457$ (2006) (repealed 2010).

85. $\$ 2457$ (a) (repealed 2010).

86. How to License NASA Technology, NASA Tech. Transfer Program, https://technology.nasa.gov/license (last visited Sept. 3, 2019).

87. Launch your Tech with Startup NASA, NASA Tech. Transfer Program, https://technology.nasa.gov/startup (last visited on Sept. 3, 2019).

88. Public Domain, NASA Tech. Transfer Program, https://technology.nasa.gov/publicdomain (last visited Sept. 3, 2019). 


\section{B. Innovation in NewSpace}

The space industry as we know it is changing. With the retirement of the Space Shuttle, the United States was left without an official government launch vehicle. To fill this gap, a group of economically incentivized and privately owned space companies have emerged. These NewSpace companies will serve as key innovators in the space industry moving forward. This group includes some of the old-guardcontractors such as Boeing and Lockheed Martin. New billionairebacked contenders such as Space Exploration Technologies ("SpaceX") and Blue Origin have entered the ring, innovating quickly and changing the industry. These NewSpace companies are developing technology for novel or space-adapted business models that take advantage of the previously untapped opportunities space offers.

A big change these companies bring is that they typically develop technologies using funds from private investors, so they do not have to give the United States ownership over their inventions as past government contractors did. That is not to say they do not sell their services to the government. However, because NewSpace companies are not developing technology for the government under a contract, they are not subject to these compulsory licensing requirements. ${ }^{89}$ This has shifted the ownership of these developing technologies to private entities.

One of the primary and notable NewSpace activities has been selling rocket launch services. Commercial launch services are the obvious first novel commercial services to develop because other space services rely on them and they have available customers in government and communication satellite companies. Smaller start-ups relying on novel business models and new technologies are also emerging. These businesses have yet to develop into the commercial stage, and it is hard to see where they will go. Private investment in these mostly satellite based start-ups is growing exponentially - the first quarter of 2017 saw $\$ 500$ million in private investments, which grew to $\$ 1$ billion by the second quarter of $2018 .{ }^{90}$ However, innovation for launch services is especially important to the space industry as a whole because every other space service relies on launch services. As such, this Section will focus on innovation within the NewSpace launch sector.

Putting payloads such as satellites into orbit for the government or commercial satellite companies has slowly become profitable. SpaceX currently charges either $\$ 62$ million or $\$ 90$ million for launch services, depending on the needs of the customer and the model of rocket cho-

89. See 51 U.S.C. § 20135 (2012).

90. Jeff Foust, "Golden Period" for Space Startup Investment Continues, Space News, (Sept. 20, 2018), https://spacenews.com/golden-period-for-space-startup-investment-continues/. 
sen. ${ }^{91}$ United Launch Alliance ("ULA"), SpaceX's main commercial competitor, has claimed to have an average launch price of around $\$ 225$ million..$^{92}$ One of the main customers of these NewSpace launchfocused companies remains the United States government, whose Space Shuttle program cost approximately $\$ 450$ million per launch before it was shut down. ${ }^{93}$

Commercial launch activity has increased significantly, and SpaceX's share of the market has steadily increased. In 2016, there were 11 total commercial launches in the United States, and SpaceX's Falcon 9 vehicle made up seven of them (63.6\%). ${ }^{94}$ In 2017, the number of commercial launches doubled with 22 launches of which 17 used the Falcon 9 (77.3\%). ${ }^{95}$ Through 2018 SpaceX has launched 20 vehicles out of 28 total United States commercial launches $(71.4 \%) .{ }^{96}$ While the increase in total launches shows an expanding commercial launch industry, the lack of significant competition is a worrying trend.

SpaceX has become a natural monopoly in the commercial launch industry. While it does not control the market with government granted monopoly or patents, its superior technology leads to much lower prices than competitors. ${ }^{97}$ Its prices will also only decrease as it further develops reusable rocket technology. ${ }^{98}$

High barriers to entry make it difficult for a true competitor to SpaceX to emerge. Space technology tends to have extremely long research and development timelines. ${ }^{99}$ It will most likely be many

91. Capabilities \& Services, SpACEX, https://www.spacex.com/about/capabilities (last visited Sept. 6, 2019).

92. Mike Gruss, News from the 30th Space Symposium, Space News (May 21, 2014), https://spacenews.com/40637news-from-the-30th-space-symposium-respondingto-critics-ula-discloses/.

93. Kennedy Space Center: Space Shuttle and International Space Station, NASA, https://www.nasa.gov/centers/kennedy/about/information/shuttle_faq.html\#10 (last updated Aug. 3, 2017).

94. The Annual Compendium of Commercial Space Transportation: 2017, Fed. Aviation Admin. (Jan. 2017), https://www.faa.gov/about/office_org/headquarters_offices/ast/media/2017_AST_Compendium.pdf.

95. The Annual Compendium of Commercial Space Transportation: 2018, Fed. Aviation Admin. (Jan. 2018), https://www.faa.gov/about/office_org/headquarters_offices/ast/media/2018_ast_compendium.pdf [https://perma.cc/7PZ9-KE3J].

96. 2018 Space Launch Report, SPACE LAUNCH REP., http://www.spacelaunchreport.com/log2018.html [https://perma.cc/8MSF-C85R] (last updated Dec. 29, 2018); Launches, Fed. Aviation Admin., https://www.faa.gov/data_research/commercial space_data/launches/?type=licensed [https://perma.cc/9AZM-TJ76] (last modifie $\bar{d}$ Feb. 27, 2018).

97. Jason Davis, How Much Does Space Travel Cost?, NBC News (Oct. 15, 2018, 10:46 AM), https://www.nbcnews.com/mach/science/how-much-does-space-travelcost-ncna919011; Reusability, SpACEX, https:/www.spacex.com/reusability-key-making-human-life-multi-planetary (last visited Sept. 6, 2019).

98. The Why and How of Landing Rockets, SPACEX (June 25, 2015), https:// www.spacex.com/news/2015/06/24/why-and-how-landing-rockets.

99. Lorrie A. Davis \& Lucien Filip, How Long Does It Take to Develop and Launch Government Satellite Systems?, Int'l Cost Estimating \& Analysis Ass'N 
years until a competitor develops a new launch system that is technologically and economically equal to SpaceX's current Falcon 9 or Falcon Heavy. On top of this, rocket launch systems take a vast amount of capital to develop. NASA has confirmed the first version of SpaceX's Falcon 9 cost $\$ 390$ million to develop. ${ }^{100}$ Even that development cost is lower than normal with NASA predicting their own development cost for a similar launch vehicle to be between $\$ 1.7$ and $\$ 4$ billion. ${ }^{101}$ Very few start-ups or well-established companies would have the time, money, or personnel available to invest in the technology required for their own competing launch system.

Some of these costs would be mitigated if SpaceX disclosed its technological developments through patents, but SpaceX seems to avoid using patents as a means of intellectual property protection. In an interview with Wired Magazine, Elon Musk said, "[w]e have essentially no patents in SpaceX. Our primary long-term competition is in China-if we published patents, it would be farcical, because the Chinese would just use them as a recipe book."102 This statement is supported with a quick patent search-it seems that only one patent and one patent application has been assigned to SpaceX. ${ }^{103}$ SpaceX seems to be foregoing patent protection and securing its current spot as the leader in the commercial launch market using its monopoly status and trade secrets to protect its technology.

Because SpaceX does not disclose their technology through patents, it most likely relies on trade secret law for protection. I will assume that SpaceX has made technological innovations because of its much lower prices and ability to land reusable rockets. ${ }^{104}$ If SpaceX is not disclosing these inventions, the inventions are secrets protectable by trade secret law, as long as reasonable protections are taken.

SpaceX has no motivation to disclose their inventions-they do not need the monopoly granted by patents, as they have effectively al-

(Mar. 12, 2015), http://www.iceaaonline.com/ready/wp-content/uploads/2014/03/Davis-Satellite-ICEAASoCal-090915.pdf ("Although there are examples of government satellites taking 10 years or more to develop and launch, the data reflects that, on average, it takes $71 \frac{1}{2}$ years to develop and launch a first vehicle, and just over 3 years to assemble and launch subsequent vehicles.").

100. Commercial Market Assessment for Crew and Cargo Systems Pursuant to Section 403 of the NASA Authorization Act of 2010, NASA 40 (Apr. 27, 2011) https:// www.nasa.gov/sites/default/files/files/Section403(b)CommercialMarketAssessment ReportFinal.pdf.

101. $I d$.

102. Chris Anderson, Elon Musk's Mission to Mars, Wired Mag. (Oct. 21, 2012), https://www.wired.com/2012/10/ff-elon-musk-qa/.

103. Patent Assignment Search for 'Space Exploration Technologies', U.S.PAт. \& Trademark OFF., https://assignment.uspto.gov/patent/index.html\#/patent/search/result id $=$ space $\% 20$ exploration $\% 20$ technologies\& type=PatAssigneeName (last visited Sept. 6, 2019).

104. See Elon Musk, Making Life Multiplanetary, 6 New Space: J. of Space EnTREPRENEURSHIP \& INNOVATION (Mar. 1, 2018), https://www.liebertpub.com/doi/ 10.1089/space.2018.29013.emu. 
ready obtained a natural monopoly, and there is little danger of competitors easily discovering the technology. There is no danger of a competitor reverse engineering a SpaceX rocket-SpaceX is selling the service of launching payloads into space and not their rockets, so competitors have no access to the rockets themselves. Independent invention would be the only way a competitor could obtain the technology legally.

Competitors will also have problems with independently inventing and then commercializing a competing launch system. The long development time and high monetary investment required to independently invent a similarly advanced launch system deters competitors. Also, a new launch system would not have the proven reliability of SpaceX's Falcon 9. Launch failure can cause customers to lose huge investments, so customers would not have a reason to choose a competitor's launch vehicle without a large economic incentive to do so.

SpaceX maintains a difficult-to-break monopoly over the space launch industry and neither discloses its innovations nor provides a service that the public can take advantage of. Its use of secrecy to protect its inventions is at odds with one of intellectual property law's main purposes-incentivizing innovation so the public can benefit. ${ }^{105}$ The currently secret discoveries made by SpaceX and other NewSpace companies could potentially greatly benefit the public by accelerating innovation of both competing companies and non-space industry companies. Policy makers should consider methods of balancing the disclosure of secret space inventions with secrecy from competitors in the industry to ensure this emerging industry continues to thrive.

\section{Balancing Secrecy and Disclosure in NewSpace}

SpaceX's present and increasing monopoly on launch systems combined with NewSpace companies' disincentive to disclose inventions has created a disconnect between space technology development and public benefit. A balance must be found between disclosure of inventions for the public's benefit and secrecy of inventions in the space industry. Secrecy and disclosure of information have different benefits for the public, and their relationship must also be examined within the space industry to determine how to best benefit the public. The effects of innovation and intellectual property policy are difficult to quantify and predict, but examining scholarly articles and history in the light of NewSpace trends allows us to make educated guesses on what will most effectively benefit society.

Maintaining secrecy allows emerging companies to retain a competitive advantage and become the first to market in space. The competitive advantage secrecy brings could create a long-term benefit for the public by increasing the pace at which space is commercialized. The

105. See supra, Section I. 
faster companies commercialize outer space, the faster the public will benefit from new opportunities, such as increased satellite communications capabilities, increased available resources from asteroid mining, and commercial space travel. However, the unique environment of the space industry alters the typical secrecy-disclosure innovation balance. The traditional downsides to choosing secrecy over a patent are no longer or much less relevant. The long development times, inability to reverse engineer, and extremely high costs of independently inventing create an insurmountable barrier for new-entrants or other companies to discover the useful information. ${ }^{106}$

Alternatively, encouraging patents and disclosure of new information can benefit the public in the short-term and potentially allow those long-term benefits to be seen sooner. Other space companies can license patents for their own businesses or use the information to develop improvements on the patented invention. The public can also use the information disclosed in patent applications for space technologies applied to other fields.

Policy makers must consider whether to let the free-market take its course or to take a more direct approach and introduce legislation to encourage disclosure of inventions in the commercial space industry as they have with the aerospace industry in the past. I will discuss the benefits of the free-market and a more active approach. I believe the government could mitigate the negative effects of a commercial space launch monopoly with a more active approach that encourages patenting space inventions.

\section{A. The Free-Market Approach}

The first and simplest solution to the above problem is to allow the industry to develop without government intervention. Allowing the free-market to take its course can regulate innovation by promoting competition within the industry. No government action is necessary for this approach besides the licensing of launch vehicles and granting of contracts, so it is the simplest to follow. This seems to be the current policy towards encouraging innovation in the space industry. The major consideration when examining this approach is if SpaceX's launch monopoly is discouraging innovation presently or if it is likely to in the future.

SpaceX's current monopoly on launches does not seem to be discouraging innovation. In fact, a temporary monopoly is a normal part of innovation, whether it comes from a patent or from being the first and only actor with that innovation for a period of time. ${ }^{107}$ Many

106. See supra, Section II.

107. See generally Joseph Alois Schumpeter, Capitalism, Socialism \& DemocRACY (1942) (arguing that some degree of monopoly is preferable to perfect competition). 
scholars believe some form of monopoly is good for innovation. ${ }^{108}$ The commercial space industry has been growing in the launch and satellite sectors. There does not seem to be an immediate harm to monopoly in the launch sector on the NewSpace industry as a whole.

The problem with a monopoly begins when a monopoly continues without competition and becomes oppressive to innovation and the public benefit. If SpaceX remains unchallenged in the space launch industry, there is a dangerous and likely possibility that its monopoly will stifle innovation in the industry. As discussed above, the long time it takes to develop space technology and then make it a profitable business combined with the high costs of independently inventing space launch technologies decreases the likelihood that SpaceX will face competition in the next few years. ${ }^{109}$ As a launch company, SpaceX will also control all other NewSpace business's entry into space. This is extremely dangerous, especially considering SpaceX is already entering the satellite communications industry where many other NewSpace companies are aiming. ${ }^{110}$ SpaceX may be aiming beyond the space launch and telecommunications industries also. SpaceX will have the ability to control their own competitor's entry into space if it maintains its monopoly on launches.

While innovation in the NewSpace industry may be currently booming, there is still a high risk that a long-term monopoly by SpaceX will harm innovation in the entire NewSpace industry. NewSpace seems to be in the aforementioned pioneering stage of innovation where intellectual property plays no role, but if past industries are an indicator, it will soon enter the stage where innovation slows and intellectual property is widely enforced. ${ }^{111}$ A more active approach by the government would mitigate the risks presented by allowing SpaceX to remain unchallenged in the free market and the lack of balances for trade secret use within the industry. Legislation could be used, as it has been in the past, to promote competition within the industry and ensure efficient innovation that can also benefit the public. Trade secrets would remain a significant part of innovation and competition in the space industry, especially on unpatentable and non-technological subject matter, but their use without the normal balances should not hinder innovation in the industry.

\section{B. The Active Government Approach}

A second and more active approach would be to use legislation to encourage widespread use of information discovered by NewSpace

108. Id.

109. Supra Section II.B.

110. Caleb Henry, FCC approves SpaceX constellation, denies waiver for easier deployment deadline, SPACE NEWs (Mar. 29, 2018), https://spacenews.com/us-regulatorsapprove-spacex-constellation-but-de.

111. See generally Boldrin \& Levine, supra note 28. 
companies. The United States government has intervened in the aerospace and space industries previously to encourage innovation and minimize wasted resources and time in such a vital industry. ${ }^{112}$ An active approach offers a chance to create a better balance between encouraging innovation and giving the public a benefit from the inventions in the space industry. However, it would be difficult to implement. There are many ways the United States could take an active approach towards this issue. I believe that a good way to encourage innovation in NewSpace is a two-step process. The first step is encouraging the patenting of space-related-inventions using government awarded contracts. The second step is to create a patent pool for space related inventions.

First, the government should make encouraging NewSpace companies to patent their inventions a priority, especially in the launch sector. As discussed above, the disclosure of information that comes with these patents would allow long-term competition while rewarding companies with a short-term monopoly and provide the public a benefit by allowing these discoveries to potentially be used in ways that will benefit them. ${ }^{13}$ Trade secrets create monopolies that are difficult to overcome in the space industry without government intervention and should be discouraged in the launch sector, which the rest of the space industry relies on. ${ }^{114}$ Encouraging the patenting of NewSpace company technologies can be done in two different ways.

The first method of encouraging the patenting of NewSpace technology is for the government to award their launch or satellite contracts to companies that patent the inventions the government's contract will touch. Government agencies should use their discretion to determine if a company's patent is relevant to the subject of the contract and give preference to companies that have patents on the invention that is the subject of that contract. The government would have to make explicit that they will be giving contract preference to companies that have patents on their inventions. This should naturally cause more space companies to start patenting inventions and discoveries and create competition in a race for development of new space technologies and the subsequent submission of the relevant patent application.

The second method of encouraging the patenting of space technology is for the government to spend significant resources on contracting companies to develop these technologies. Specifically, NASA should contract out the development of new space launch systems. As discussed above, when an invention is made in the performance of a NASA contract, NASA retains the rights to that invention. ${ }^{115}$ NASA

112. Supra Section II.A.

113. Supra Section I.

114. See supra Section II.

115. See 42 U.S.C. $\$ 2457$ (a) (2006) (repealed 2010). 
should patent the inventions in these contracted launch systems themselves. However, they should allow the commercial entity that develops these launch systems the right to use the patents without a licensing fee. This would encourage the developer of the launch technology to enter the commercial launch market and compete with SpaceX. NASA would still retain the ownership of the invention and use their ability to license out the technology at their discretion to benefit the public, as they do with their current patents. ${ }^{116}$

There are other methods of encouraging patent use in the space industry, but these methods require more direct legislation that would be difficult to implement and could potentially negatively impact other industries. For example, strengthening the patent system or patent protection would make companies more likely to use patents to protect their inventions. Contract granting is relatively simple compared to a broader intellectual property reform. This process can have the same effect of encouraging patenting in NewSpace and can still be achieved with minimal legislation. The downside of the above described methods is the large amount of funds it would take for these contracts. However, the government has already begun to use contracts to encourage innovation and competition within the space industry. On October 10, 2018, the United States Air Force and Department of Defense awarded contracts of \$967 million, \$792 million, and $\$ 500$ million to United Launch Alliance, the Northrop Grumman owned Orbital Sciences Corp., and Blue Origin respectively. ${ }^{117}$ The government should ensure that important inventions that result from these contracts are patented. If the development of these launch systems results in a competitive launch environment, the free-market would be sufficient to regulate the launch industry. However, SpaceX's planned next generation rocket, called "BFR," is planned to be fully reusable and lift up to 150 tons, which will most likely be greater than the air-force-contracted-launch systems. ${ }^{118}$ If SpaceX maintains control of the launch industry, the government will need to continue investing in the development of commercial launch systems.

A second step for encouraging innovation in the space industry is to create a patent pool of space technologies that are subject to compulsory licensing. Previously, the aerospace industry in the United States has had problems with monopoly and excessive patent litigation slowing innovation. ${ }^{119}$ The United States government should learn from

116. See supra Section II.

117. Contracts, DeP'T OF DEF., https://dod.defense.gov/News/Contracts/ContractView/Article/1658771/ (last visited Sept. 9, 2019).

118. Elon Musk, Making Life Multiplanetary, 6 (abridged transcript 2017), https://www.spacex.com/sites/spacex/files/making_life_multiplanetary_transcript_ 2017.pdf.

119. See supra Section II. 
the past and enact a patent pool for space-launch-related patents. Patents in this pool would be subject to compulsory licensing for a reasonable royalty paid to the patent holder.

A patent pool of space-launch-technologies would increase competition within the launch industry. Space-launch-technologies such as propulsions chemicals, engine technologies, rocket body materials, and rocket control systems can be used by different entities in separate launch systems and in separate business models. Currently, the space launch industry earns around $\$ 5.5$ billion annually. ${ }^{120}$ Compared to the $\$ 339.1$ billion total the global space economy generates, the launch industry accounts for less than $2 \%$ of total earnings. ${ }^{121}$ Increased competition within the launch industry is good for NewSpace as a whole because it lowers the price to get to space, where nonlaunch NewSpace companies that make up a majority of the space industry will do business and provide a benefit for the public. Launch systems should not be a barrier to the space industry-the focus should the new opportunities that having access to space brings.

The suggested patent pool is contingent on successfully encouraging the patenting of space-launch-technologies to where entire space launch systems would be a part of it. A patent pool for space-launchtechnologies will be useless unless there are patents to put in the pool. The patent pool will be a benefit even with patents that form a single launch system because improvements could be made on these patents and more advanced launch systems could be created.

A patent pool would also help overcome the possibility of a patent thicket developing. A patent thicket may develop because of the complexity of the launch systems. Launch systems, satellites, and spacecraft require a multitude of inventions to both be manufactured and work. If each of these inventions is protected by patents owned by different companies, a patent thicket is likely. ${ }^{122}$ As the NewSpace industry grows and more specialized inventions develop, patent thickets are more likely to develop because launch companies will need to use a variety of specialized inventions to create new rockets. A patent pool would ensure a company could develop what they wanted despite restrictions from often criticized parts of patent law. ${ }^{123}$

\section{Conclusion}

The space industry is shifting towards new commercial companies using innovative technologies and novel business methods. This Article analyzes the changing space industry in light of intellectual prop-

120. Bryce Space \& Technology, State of the SAtellite Industry Report, 7 (Satellite Industry Association, 20th ed. 2017), https://www.sia.org/wp-content/ uploads/2017/07/SIA-SSIR-2017.pdf.

121. Id. at 24.

122. See supra Section I.A.2.

123. Id. 
erty and innovation policy. It also reviews previous government action on intellectual property in the space industry. I conclude that SpaceX has a monopoly on commercial launch services and that its use of secrecy to protect their inventions could extend their monopoly dangerously and damage innovation throughout the NewSpace industry. The free-market may be able to naturally allow for innovation or competition within the industry, but it is not definite. Instead, I propose that the patenting of space-launch-technologies is encouraged by the government through their use of space technology contracts. These patents would disclose new technologies and information and help promote present and future innovation. As a secondary measure, I also propose a patent pool for space-related-technologies to encourage innovation within the industry, as the government has done in the past. 
